\title{
BENTUK PENYAMPAIAN MORAL DALAM NOVEL BULAN KERTAS KARYA ARAFAT NUR
}

\author{
oleh \\ Siti Nurhaliza, Radhiah, \& Masithah Mahsa* \\ *Dosen Program Studi Pendidikan Bahasa Indonesia, FT Universitas Malikussaleh \\ surel: masithahmahsa@unimal.ac.id
}

\begin{abstract}
ABSTRAK
Penelitian ini bertujuan untuk mendeskripsikan bentuk penyampaian moral dalam novel Bulan Kertas karya Arafat Nur. Bentuk penyampaian moral terbagi atas dua, yaitu bentuk penyampaian langsung dan bentuk penyampaian tidak langsung. Jenis penelitian yang digunakan dalam penelitian ini adalah deskriptif kualitatif. Penelitian ini dilakukan dengan menggunakan pendekatan objektif. Teknik pengumpulan data yang digunakan dalam penelitian ini adalah teknik baca catat. Berdasarkan hasil penelitian ditemukan bahwa bentuk penyampaian langsung dalam novel Bulan Kertas karya Arafat Nur dilihat dari uraian pengarang dan uraian tokoh, sedangkan bentuk penyampaian tidak langsung dilihat dari peristiwa dan konflik. Jumlah data bentuk penyampaian langsung yaitu 23 data yang terdiri dari 5 data berupa uraian pengarang dan 18 data berupa uraian tokoh. Data dari bentuk penyampaian tidak langsung berjumlah 21 data yang terdiri dari 6 data berupa persitiwa dan 15 data berupa konflik.
\end{abstract}

Kata Kunci: novel Bulan Kertas, bentuk penyampaian moral, langsung, tidak langsung 


\section{PENDAHULUAN}

Karya sastra adalah bentuk kreativitas dalam bahasa yang indah berisi sederetan pengalaman batin dan imajinasi yang berasal dari penghayatan realitas sosial pengarang (Wicaksono, 2014: 1). Salah satu jenis karya sastra adalah novel. Novel dibangun atas dua unsur, yakni unsur intrinsik dan unsur ekstrinsik. Unsur intrinsik merupakan fondasi dasar dari karya sastra, sedangkan. unsur ekstriksik adalah unsur-unsur yang terdapat di luar karya sastra yang mempengaruhi karya sastra tersebut. Unsur ini membuat suatu karya sastra memiliki nilai dan terkait hubungan dengan tersendiri dalam sosial masyarakat. Salah satu unsur novel yang paling penting adalah nilai moral. Bentuk penyampaian moral dalam novel bersifat langsung dan tidak langsung. Bentuk penyampaian moral yang bersifat langsung biasanya memperkenalkan tokoh utama dengan seluruh kepribadiannya melalui aktivitas tokoh ataupun penutur langsung pengarang. Biasanya disampaikan lewat dialog, tingkah laku dan pikiran tokoh yang terdapat dalam cerita tersebut. Berbeda dengan bentuk penyampaian moral tidak langsung. Bentuk penyampaian moral ini bersifat multitafsir, sehingga pembaca belum tentu dapat menangkap apa sesungguhnya yang dimaksudkan pengarang.

Novel Bulan Kertas karya Arafar Nur ini menceritakan tentang dua orang yang memiliki kepribadian yang berbeda dengan orang lain. Novel ini juga memberikan pelajaran mengenai pergaulan remaja ketika menghadapi masalah dengan teman, guru maupun dengan orang tua. Dalam novel ini konflik yang dialami tokoh utama sangat mendominasi alur cerita, psikologis para tokoh juga sulit ditebak. Alasan peneliti memilih penelitian ini adalah karena belum banyak penelitian yang menganalisis bentuk penyampaian moral dalam novel.
Penelitian sebelumnya pernah dilakukan oleh Wahida (2017) dengan judul Analisis Pesan Moral dalam Novel Surga yang Tak Dirindukan Karya Asma Nadia. Berdasarkan hasil penelitian dapat disimpulkan bahwa dalam novel mengandung banyak pesan moral diantaranya dampak poligami terhadap perempuan. Bagaimana poligami dapat mempengaruhi rumah tangga yang telah dibangun bertahun-tahun. Relevansi penelitian Karima dengan penelitian ini adalah sama-sama membahas moral dalam novel, sedangkan perbedaannya terletak pada masalah yang dibahas. Jika dalam novel Karima membahasa nilai moral, sedangkan penelian ini membahas bentuk penyampaian moral. Penelitian selanjutnya dilakukan tahun 2019 oleh Kurniadi Analisis Nilai Moral dan Nilai Sosial dalam Novel Daun yang Jatuh Tak Pernah Membenci Angin Karya Tere Liye dan Implementasinya oleh Kurniadi. Persamaan penelitian Kurniadi dengan penelitian ini adalah sama-sama menganalisis nilai moral, sedangkan perbedaannya penelitian Kurniadi membahas nilai moral dan nilai sosial, sedangkan penelitian ini membahasa bentuk penyampaian moral. Berdasarkan uraian di atas, maka judul dalam penelitian ini adalah Bentuk Penyampaian Moral dalam Novel Bulan Kertas Karya Arafat Nur.

\section{TINJAUAN TEORITIS}

Novel adalah karya imajinatif yang mengisahkan sisi utuh atas problematika kehidupan seseorang atau beberapa orang tokoh (Kosasih, 2012: 60). Novel atau sering disebut sebagai roman adalah suatu cerita prosa yang fiktif dalam panjang yang tertentu, yang melukiskan para tokoh, gerak serta adegan nyata yang representatif dalam suatu alur atau suatu keadaan yang agak kacau atau kusut (Tarigan, 2011: 167). Nurgiyantoro (2010: 10) mengemukakan bahwa novel merupakan karya fiksi yang dibangun oleh unsur-unsur pembangun, yakni unsur 
intrinsik dan unsur ekstrinsik. Novel juga diartikan sebagai suatu karangan berbentuk prosa yang mengandung rangkaian cerita kehidupan seseorang dengan orang lain di sekelilingnya dengan menonjolkan watak dan sifat pelaku. Memperhatikan beberapa pendapat di atas dapat disimpulkan bahwa novel adalah prosa fiksi yang berbentuk narasi dan memiliki unsur yang membangun sebuah karya. Novel menceritakan kehidupan yang sudah dipengaruhi dengan ide kreatif atau imajinasi dari pengarang. Sadar atau tidak pengarang menuliskan kehidupan disekitarnya dengan pengungkapan cerita dibuat seimajinatif yang pengarang inginkan.

Novel dibangun atas dua unsur yaitu unsur intrinsik dan unsur ekstrinsik. Unsur intrinsik novel terdiri atas tema, penokohan, alur, latar, amanat, sedangkan unsur ekstrinsik terdiri dari nilai-nilai yang terkandung dan sudut pandang pengarang. Januarini (2013: 15) menyebutkan bahwa tema merupakan ide yang mendasari suatu cerita. Tema terbentuk dari sejumlah ide, tendensi, motif, atau amanat yang sama, yang tidak bertantangan satu dengan lainnya. Dapat dikatakan bahwa tema merupakan ide pokok, ide sentral, atau ide yang dominan dalam karya sastra. Penokohan adalah pelukisan gambaran yang jelas tentang seseorang yang ditampilkan dalam sebuah cerita, sedangkan latar adalah tempat atau waktu terjadinya peristiwa-peristiwa yang terjadi dalam sebuah karya sastra (Padi ed, 2013: 8). Latar adalah situasi tempat, ruang dan waktu terjadinya cerita (Wicaksono, 2014: 208).

Alur merupakan unsur fiksi yang penting, bahkan bisa jadi orang menganggapnya sebagai unsur fiksi yang paling penting dibandingkan unsur fiksi lainnya (Wicaksono, 2014: 128). Sejalan dengan pendapat tersebut bahwa alur merupakan pola pengembang cerita yang terbentuk oleh hubungan sebab akibat (Kosasih, 2012: 63). Dapat dikatakan bahwa alur cerita adalah bagaimana kejadian-kejadian yang dirangkai yang biasanya berdasarkan hubungan sebabakibat, mulai dari titik awal cerita sampai klimaks yang kemudian mencapai sebuah resolusi atau penyesuaian. Peristiwaperistiwa yang membuat alur cerita adalah persoalan-persoalan yang menimbulkan konflik. Amanat merupakan ajaran moral atau pesan didaktis yang hendak disampaikan pengarang kepada pembaca melalui karyanya itu (Kosasih, 2012: 71). Amanat umumnya diungkapkan secara implisit dan eksplisit di dalam karya sastra.

Moral merupakan sesuatu yang ingin disampaikan oleh pengarang kepada pembaca, yang merupakan makna yang terkandung dalam sebuah karya sastra dan makna yang disarankan lewat cerita (Nurgiantoro, 2013: 321). Hal ini berarti pengarang menyampaikan pesan-pesan moral kepada pembaca melalui karya sastra baik penyampaian secara langsung maupun tidak langsung. Moral pada kenyataannya membicarakan tentang persoalan benar atau salah, apa yang perlu dilakukan dan ditinggalkan atas sebabsebab tertentu yang mengakibatkan timbulnya "pengadilan" dari masyarakat mengenai tindakan yang telah dilakukan oleh seorang individu. Pertimbangan moral tergantung kepada suasana atau keadaan yang membentuk individu tersebut. Misalnya, sistem sosial, kelas sosial dan kepercayaan yang dianut. Moralitas dalam diri manusia mnerupakan kesadaran tentang baik buruk, tentang larangan, tentang yang harus dilakukan, dalam setiap tindakan manusia secara tidak langsung dibebani oleh tanggung jawab moral yang harus selalu dipatuhi.

Moral yang berlaku di masyarakat bersifat mengikat terhadap setiap individu pada segala lapisan masyarakat yang ada. Setiap individu dalam bersikap, bertingkah laku, dan bergaul dalam masyarakat haruslah memperhatikan tatanan yang ada. Selain melakukan apa yang ditugaskan kepadanya oleh kehidupan sosial dan oleh nasib 
pribadinya. Dari semua paparan di atas dapat disimpulkan bahwa pada prinsipnya moral merupakan kualitas perbuatan manusia didasarkan pada nilai-nilai luhur yang mengatur tingkah laku manusia dalam masyarakat untuk melaksanakan perbuatan-perbuatan yang baik dan benar yang timbul dari hati nurani tanpa paksaan dan disertai tanggung jawab. Manusia memiliki hak dan kewajiban masingmasing agar tidak melanggar prinsip kesusilaan maka moral digunakan sebagai penilaian terhadap tingkah laku seseorang.

Bentuk penyampaian moral terbagi atas dua yaitu bentuk penyampaian secara langsng dan bentuk penyampaian tidak langsung. Bentuk penyampaian pesan moral yang bersifat langsung identik dengan cara pelukisan watak tokoh yang bersifat uraian, telling, atau penjelasan, expository. Dalam hal ini, pengarang tampak bersifat menggurui pembaca, secara langsung memberikan nasihat dan petuahnya (Nurgiantoro, 2013: 461). Sebaliknya bentuk penyampaian tidak langsung adalah pesan tersirat dalam cerita yang berpadu secara koherensif dengan unsur-unsur cerita yang lain. Bentuk penyampaian ini merupakan hal yang esensial dalam karya sastra. Hubungan yang terjadi antara pengarang dengan pembaca adalah tidak langsung dan tersirat. Kurang ada pretensi pengarang untuk langsung menggurui pembaca sebab yang demikian justru tidak efektif disamping juga merendahkan kadar literer karya yang bersangkutan. Bentuk penyampain tidak langsung dilihat dari peristiwa dan konflik yang ada dalam cerita.

\section{METODE PENELITIAN}

Metode yang digunakan dalam penelitian ini ialah metode penelitian deskriptif kualitatif. Deskriptif kualitatif adalah penelitian yang bermaksud bertujuan untuk memahami fenomena tentang apa yang dialami oleh subjek penelitian misalnya perilaku, persepsi, motivasi, tindakan dan lain-lain
(Moleong, 2013: 5). Dalam metode kualitatif, data yang terkumpul diinterprestasikan secara objektif, kemudian dideskripsikan sesuai dengan tujuan penelitian. Data dalam penelitian ini adalah novel Bulan Kertas Karya Arafat Nur, sedangkan sumber datanya berupa kata-kata dan kalimat dalam novel tersebut. Teknik pengumpulan data yang digunakan adalah Teknik baca dan catat, sedangkan teknik analisis datanya menggunakan teknik analisis isi.

\section{HASIL DAN PEMBAHASAN}

Bentuk penyampaian moral dalam novel Bulan Kertas karya Arafat Nur terbagi atas dua, yaitu bentuk penyampaian langsung dan tidak langsung. Bentuk penyampaian langsung terdiri dari uraian pengarang dan uraian tokoh. Bentuk penyampaian tidak langsung terdiri dari peristiwa dan konflik. Berdasarkan hasil penelitian, bentuk penyampaian langsung berjumlah 23 data, sedangkan bentuk penyampaian tidak langsung sebanyak 21 data. Hasil penelitian tersebut akan dijabarkan sebagai berikut.

\section{a. Bentuk Penyampaian Langsung}

\section{Melalui Uraian Pengarang}

Pengarang menyampaikan pesan moral melalui uraian yang ditunjukkan kepada pembaca. Uraian tersebut disampaikan berupa narasi yang terdapat dalam novel Bulan Kertas. Sebagai tokoh yang bercerita dalam novel ini, Rafa menyinggung tentang kegiatan yang seharusnya tidak dilakukan oleh orangorang yang berperan sebagai pendidik. Hal tersebut dapat dilihat dari kutipan berikut.

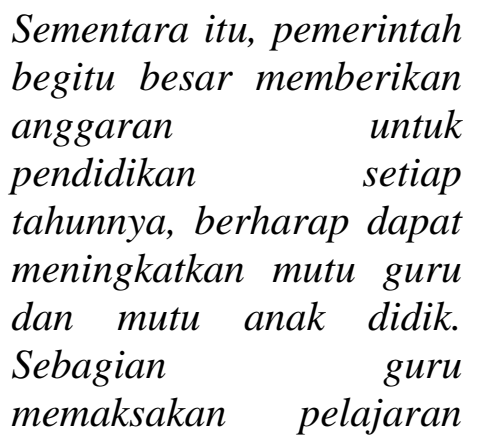


pada siswa agar betul-

betul dapat menguasai materi kurikulum yang diwajibkan. Sudah pasti tidak akan bisa. Ini akibat sistem pendidikan yang salah mata pelajaran yang terlampau banyak dijejalkan, ditambah lagi para guru yang tidak menjiwai pekerjaannya sebagai pengajar, sempurnalah kehancuran pendidikannya.

Kemudian dibuatlah jalan pintas yang bukan lagi rahasia, yang semakin merusak citra pendidikan. Jawaban soal ujian nasional dijadikan barang dagangan yang bisa dibeli secara bebas. Malahan orang-orang dinas, guru dan kepala sekolah, ikut terlibat menawarkan kunci jawaban dengan harga tertentu, kadang-kadang memaksa dengan ancaman, bila tidak membelinya tidak akan lulus. Jadi untuk apa lagi susah-susah belajar jika hanya mendapatkan nilai yang buruk?.

(Nur, 2017: 30)

Pada kutipan di atas, Nur menyindir tentang pendidikan yang terlampau memprihatinkan, para guruguru disekolah menjadikan sekolah sebagai ajang perekonomian bukan lagi dengan tujuan yang pada umumnya mendidik, mengajar tetapi malah membuat peraturan yang sehararusnya tidak dilakukan. Hal itu tersirat dalam kalimat "Kemudian dibuatlah jalan pintas yang bukan lagi rahasia, yang semakin merusak citra pendidikan. Jawaban soal ujian nasional dijadikan barang dagangan yang bisa dibeli secara bebas. Malahan orang-orang dinas, guru dan kepala sekolah, ikut terlibat menawarkan kunci jawaban dengan harga tertentu, kadang-kadang memaksa dengan ancaman, bila tidak membelinya tidak akan lulus." Kalimat tersebut menjabarkan hal yang dialami Rafa sebagai seorang siswa. Rafa merasa pendidikan sekarang bukanlah tujuan utama bagi guru-guru di sekolah. Namun, pendidikan hanya untuk memperoleh keuntungan pribadi dan membuat peraturan yang tidak wajar. Dalam potongan paragraf tersebut juga mengatakan bahwa jawaban ujian nasional dijadikan barang dagangan para guru, kepala sekolah bahkan orang dinas.

Uraian di atas merupakan bentuk penyampaian langsung. Uraian tersebut bukanlah untuk tokoh-tokoh dalam novel Bulan Kertas, melainkan untuk pembaca. Sindiran disampaikan dengan menggunakan bentuk penyampaian langsung. Selain itu dalam uraian ini juga terdapat data yang menjelaskan tentang sindiran yang disampaikan dalam bentu paragraf. Hal tersebut dapat dilihat dari kutipan berikut.

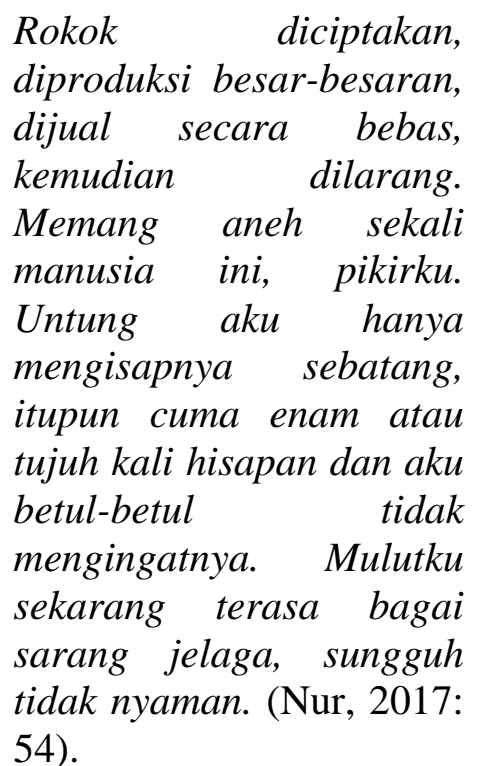

Kutipan di atas berupa uraian pengarang, Kalimat "Rokok diciptakan, diproduksi besar-besaran, dijual secara bebas, kemudian dilarang." merupakan sindiran pengarang yang disampaikan secara langsung melalui uraiannya. Rokok dilarang guna kesehatan jasmani dan 
rohani. Tidak bisa dipungkiri karena benda itu memang sengaja diciptakan bahkan sampai sekarang tidak dapat dihentikan lagi. Sering kali alasan mengapa orang merokok hanya untuk melawan kebosanan, bahkan di sisi lain masih banyak hal yang bisa dilakukan ketika bosan salah satunya membaca. Membaca dapat menghindari rasa bosan karena semakin lama kita membaca semakin jauh pula rasa ingin tau kita terhadap sesuatu. Nur menggunakan bentuk penyampaian langsung dalam uraian di atas. Nur juga membangkitkan semangat dengan cara mengingatkan kesejahteraan rakyat yang tidak pernah berubah, dikarenakan pemerintah hanya mementingkan diri sendiri dibandingkan rakyatnya. Hal tersebut bisa dilihat pada kutipan di bawah ini.

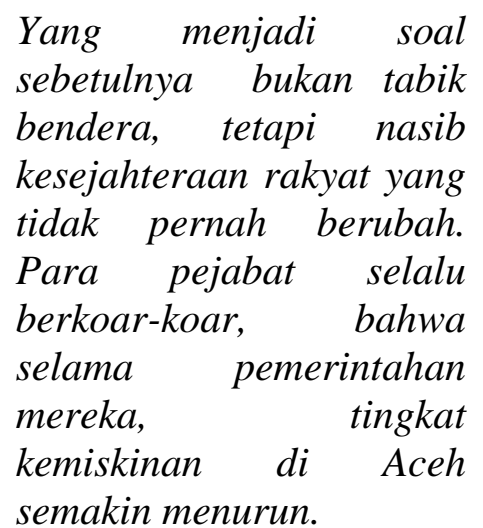

(Nur, 2017: 110).

Pada kutipan di atas Nur menjelaskan bahwa pemerintah hanya mengumbar janji kemudian lupa untuk menepatinya. Peristiwa perang selalu diceritakan oleh orang-orang yang mengalami masa tersebut, termasuk ayah dan ibu Rafa. Rafa sering kali mendengarkan cerita tentang perang dari orang-orang disekitarnya. Nur yang lahir di tengah perang Aceh, Nur menyindir pemerintah yang selalu menebarkan janji hanya untuk jabatan dan mementingkan hal pribadi dibandingkan rakyat. Moral pada kutipan di atas terdapat pada penggalan kalimat "Para pejabat selalu berkoar-koar, bahwa selama pemerintahan mereka, tingkat kemiskinan di Aceh semakin menurun." yang disampaikan secara langsung oleh Nur. Bagaimana dengan Aceh sekarang, orangorang percaya bahwa Aceh akan merdeka. Pengarang banyak sekali menyinggung hal-hal mengenai sejarah Aceh yang dulunya berperang dengan Belanda yang menuntut agar Aceh mengakui kedaulatannya pada tahun 1873. Sampai dengan sekarang Aceh belum juga merdeka. Mungkin disebabkan oleh satu hal dan hal-hal lainnya. Seperti pada kutipan di bawah ini.

"Orang-orang kampung
percaya kalau Aceh akan
merdeka sebentar lagi.
Coba pikirkan, dengan
perang yang berdarah-
darah saja tidak bisa
merdeka, apalagi hanya
dengan sebuah lambang
dan warna bendera."
(Nur, 2017: 171).

Kutipan di atas juga salah satu cara pengarang memberi semangat agar orangorang Aceh bertindak lebih tegas jika ingin merdeka. Omongan besar tidak mampu memerdekakan sebuah wilayah. Nur menyampaikan keluhannya melalui bentuk penyampaian langsung yang dalam novel. Pada kalimat "Dengan perang yang berdarah-darah saja tidak bisa merdeka, apalagi hanya dengan sebuah lambang dan warna bendera." Moral pada kalimat di atas berupa kemerdekaan sebuah wilayah harus mempunyai persetujuan dari beberapa pihak, dengan perangperang berdarah saja tidak akan membuat sebuah wilayah merdeka apalagi dengan warna bendera. Nur memberikan kesadaran terhadap rakyat yang telah tertipu dengan janji-janji yang telah diucapkan pemerintah agar dapat menjadi penguasa. Contohnya pada kutipan berikut.

Selama masa kampanye sampai memasuki minggu tenang, sejumlah peristiwa pembakaran mobil dan kantor-kantor partai terus terjadi. Seolah Aceh 
bergolak lagi. Bila dulu melawan tentara pemerintah, sekarang sesama orang Aceh sendiri saling bermusuhan; saling menebar fitnah dan kedengkian. Mereka yang dulunya lawan sekarang menjadi kawan. Sedangkan mereka yang dulunya kawan, kini telah menjadi lawan. (Nur, 2017: 173-174).

Sangat disayangkan bila harus bermusuhan antara sesama hanya karena ingin merebut sebuah jabatan. Kalimat "Bila dulu melawan tentara pemerintah, sekarang sesama orang Aceh sendiri saling bermusuhan; saling menebarfitnah dan kedengkian" kita bisa belajar dari pengalaman yang sudah ada. Jika dulu masyarakat hanya melawan tentara pemerintah tetapi sekarang malah bermusuhan dengan sesama orang Aceh. Kutipan tersebut merupakan bentuk penyampaian langsung yang digunakan Nur dalam novelnya Bulan Kertas. Bentuk penyampaian langsung yang disampaikan Nur pada kutipan di atas yang memberikan kesadaran terhadap orangorang Aceh yang telah bermusuhan dengan sesama disebabkan sebuah jabatan. Pada penggalan kalimat di atas secara langsung pembaca dapat memahami moral yang terkandung di dalamnya.

\section{Melalui Uraian Tokoh}

Dalam menyampaikan nilai moral secara langsung, pengarang juga menyampaikannya melalui tindakan tokoh. Tokoh-tokoh tersebut yaitu Naya, Rafa, Ibu Naya, dan Nafil. Naya adalah tokoh utama dalam novel bulan kertas. Naya memberikan pengaruh banyak terhadap pembaca, dalam novel ini tokoh Naya merupakan gadis remaja yang sedang menduduki bangku sekolah menengah di salah satu kota yang berada di Aceh. Tokoh Naya ini dikenal dengan sosok pendiam, tetapi tegas bila ada yang berusaha mengganggunya. Seseorang yang dikagumi oleh remaja laki-laki. Sosok Naya banyak sekali memberikan nilai moral bagi pembaca. Melalui ucapan maupun tingkah lakunya, Naya juga suka menulis dan membaca. Hal tersebut dibuktikan dalam kutipan berikut ini.

"Aku juga suka baca novel. Bisa menghilangkan stres”. (Nur, 2017: 35)

Dari kutipan di atas dapat dilihat tokoh Naya merupakan seorang yang suka membaca novel dan itu merupakan kebiasaan positif yang sangat baik di kalangan remaja. Nur menyampaikan nilai moral dalam uraiannya melalui tokoh Naya yang juga sebagai tokoh utama dalam novel Bulan Kertas. Kalimat "Aku juga suka baca novel. Bisa menghilangkan stres," berupa bentuk penyampaian moral secara langsung yang digunakan Nur dalam novelnya, dengan adanya bentuk penyampaian tersebut sehingga pembaca dapat memahami moral yang disampaikan. Bentuk penyampaian moral langsung juga disampaikan secara tersurat. Moral yang terdapat dalam kutipan di atas berupa membaca bisa menghilangkan stres.

Setiap manusia mempunyai kepribadian yang berbeda-beda. Naya tidak memilih-milih orang untuk menjadi temannya Naya pun tidak memiliki banyak teman karena Naya siswa pindahan. Salah satu teman dekat Naya yaitu Rafa, Naya memiliki kesamaan dengan Rafa yaitu sama-sama tidak mempunyai banyak teman. Sehingga Naya akan menerima siapapun yang akan menjadi temannya. Hal tersebut bisa dilihat dari kutipan berikut ini.

"Aku ini anak baru, tidak punya banyak teman,dan belum mengenal banyak orang. Siapa saja yang ingin berteman denganku, asal tidak macam-macam, akan aku terima" (Nur, 2017: 36). 
Pada kutipan di atas bisa dilihat bahwa Naya bukanlah orang yang pandai bergaul.

"Siapa saja yang ingin berteman denganku, asal tidak macam-macam, akan aku terima," kalimat tersebut berupa penyampaian moral secara langsung mengambarkan sosok Naya yang meyadari bahwa dirinya adalah anak baru disekolah tersebut. Namun, Naya akan menerima siapa saja yang akan menjadi temannya. Pengarang menyampaikan nilai moralnya secara langsung melalui tokoh Naya. Sosok Naya juga rendah hati sehingga begitu peduli kepada temannya yang satu ini, Rafa. Hal itu bisa dilihat dari kutipan berikut.

"Di rumah ada obat.

Setelah diperban, kau bisa pulang".

"Aku ini temanmu, tidak usah malu. Cuma sebentar.

Dioleskan obat luka saja, diperban sedikit, lalu kau bisa terus pulang" (Nur, 2017: 76)

Dari kutipan di atas bisa dilihat sosok Naya seorang yang sangat peduli terhadap temannya, Rafa. Kalimat " $A k u$ ini temanmu, tidak usah malu. Cuma sebentar. Dioleskan obat luka saja, diperban sedikit, lalu kau bisa terus pulang," merupakan bentuk penyampaian moral langsung berupa kepedulian terhadap teman, Nur menggambarkan tokoh Naya yang rendah hati. Hal itu dapat dilihat pada bentuk penyampaian langsung yang disampaikan Nur pada penggalan kalimat di atas. Tokoh Naya yang banyak memberikan pesan moral bagi pembaca sehingga pengarang dengan mudah menyampaikan moralnya melalui tokoh. Naya merupakan tokoh yang diceritakan dalam novel ini, tentu banyak sekali moral yang dapat disampaikan melalui tokoh Naya tersebut. Salah satunya bisa dilihat pada kutipan di bawah ini.
"Kau bukan tidak berani,

tapi kau sendirian,

sedangkan mereka bertiga.

Kalau melawannya kau

akan kalah kau menyadari

itu, makanya kau tidak

melawannya,". (Nur,

2017: 100)

Kutipan di atas merupakan moral yang disampaikan melalui tokoh, Nur menggambarkan bagaimana tokoh dalam novelnya dan bagaimana moral yang digambarkan dalam tokoh tersebut. Melalui tokoh juga berupa bentuk penyampaian langsung, maka dari itu pengarang menggunakan bentuk dari keduanya untuk menyampaikan moral dalam novel. Nur menggambarkan tokoh Naya yang berani dalam novel tersebut, Naya dan Rafa sama-sama suka membaca, bahkan bertamu ke rumah Naya saat lebaran pun mereka tetap saja membahas tentang buku dan novel. Kegemaran mereka terhadap buku tidak harus di sekolah. Hal tersebut bisa dilihat pada kutipan di bawah ini.

\section{"Hari-hari biasa di} rumah, lebaran juga di rumah, apa tidak suntuk di rumah terus? Keluarlah kalian jalan-jalan. Urusan novel bisa kapan-kapan,"

Ayah." Naya

"Membacaitu asyik,

"Kamu itu seharian

dengan buku melulu.

Pulang sekolah, pegang

buku. Malam, baca buku.

Di sekolah juga buku.

Pikiran kamu bisa rusak.

Ayo keluar, kapan lagi

kamu bergaul? Nanti kamu

jadi orang tidak normal."

(Nur, 2017: 123)

Pada kutipan di atas jelas dapat dilihat bahwa Naya tidak pernah terlepas dari buku, baginya membaca itu bisa menghilangkan stres. Kalimat "Membaca itu asyik, Ayah." merupakan bentuk penyampaian moral secara langsung 
melalui tokoh Naya. Bukan ayah Naya menyuruhnya untuk jaga jarak dengan buku, tetapi karena Naya adalah seseorang yang pikirannya sulit ditebak. Naya adalah gadis yang kerap menutup diri seolah-olah dia hidup di dunianya sendiri, ia sering menceritakan tentang dunia lain yang sulit dijelaskan. Hanya Naya yang mengerti dengan ketakutan-ketakutan yang tak beralasan. Oleh karena itu, ayahnya menyuruhnya melihat keadaan-keadan di luar agar pikirannya bisa terbuka. Jika tidak Naya hanya akan mengurung diri di kamarnya dan hanyut dalam dunianya sendiri. Kutipan di atas salah satu bentuk penyampaian langsung yang digunakan Nur melalui tokoh dalam novel. Naya dan Rafa sudah berteman sejak lama dan mereka menyadari kebaikan antara satu sama lain. Hal tersebut bisa dilihat pada kutipan di bawah.

"Kuhargai kebaikan dan ketulusanmu, Rafa. Aku tidak tahu apakah kita bisa bersama selamanya. Kalau saja tubuhku ini bisa dipotong, akan kuberikan sebagiannya untukmu"

(Nur, 2017: 207)

Naya menyadari kebaikan Rafa terhadapnya, Naya ingin membalas semua kebaikan dan kesabaran yang telah Rafa berikan padanya. Ingin membalas kebaikan dengan kabaikan namun Naya tak tahu caranya membalas kebaikan seperti yang Rafa lakukan. Naya ingin membalas budi terhadap Rafa yang selama ini sudah berjuang untuknya, walaupun Naya dan Rafa hanya sekedar berteman. Pengarang menyampaikan moralnya melalui tokoh Naya dalam novel tersebut dengan menggunakan bentuk penyampaian langsung. Tokoh Naya banyak memberikan nilai moral bagi pembaca.

Rafa adalah si $a k u$ yaitu orang yang bercerita dalam novel ini. Melalui tokoh Rafa, Nur memberikan motivasi kepada pembaca yang diuraikan dalam bentuk penyampaian langsung. Pada saat pertemuan pertama mereka, Naya tidak sengaja menabrak Rafa dan menumpahkan semua makanan Rafa. Namun, Rafa tidak marah karena Rafa tahu Naya melakukan itu tanpa sengaja. Hal tersebut dibuktikan dalam kutipan berikut ini.

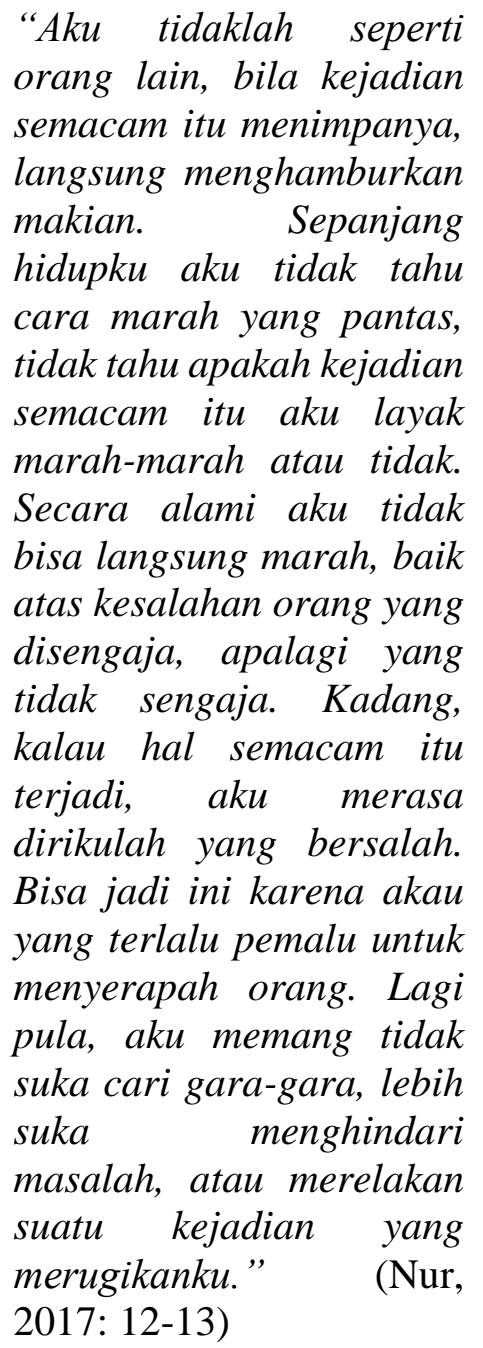

Pada kutipan di atas, Nur menjelaskan bahwa Rafa tidak seperti orang kebanyakan. Kalimat "Aku tidaklah seperti orang lain, bila kejadian semacam itu menimpanya, langsung menghamburkan makian." Merupakan moral yang disampaikan secara langsung oleh pengarang. Penyampaian moral tersebut disampaikan melalui tokoh Rafa yang merupakan tokoh utama dalam novel Bulan Kertas. Penggalan kalimat tersebut mengatakan bahwa Rafa adalah orang yang lebih suka mengalah dari pada mencari gara-gara yang menyebabkan kerugian untuknya dan orang lain. 
Rafa juga banyak memberikan pesan moral pada pembaca. Baginya membaca buku adalah hal yang tepat untuk melampiaskan rasa yang dialaminya. Salah satunya terlihat dalam kutipan berikut.

\begin{abstract}
Itu pula sebabnya sampai sekarang aku tidak lagi memikirkan tentang urusan perempuan, dan lebih suka memilih menenggelamkan diri dalam buku bacaan. Aku menganggap masa lalu indah yang menyiksa itu adalah bagian dari tahap peralihan pertumbuhanku ke masa remaja, menandakan bahwa aku sudah akil balig. Bila terus dituruti kemauan dan nafsu, justru aku kehilangan kesempatan dan memusatkan diri pada pelajaran yang kelak akan merugikan diriku sendiri. Semua ada masanya, ada tempatnya, untuk apa terlalu memaksakan diri? Begitulah kesadaran itu tumbuh, seiring dengan berkembangnya pikiranku.
\end{abstract}

(Nur, 2017: 24-25)

Pesan moral dari kutipan di atas adalah seorang remaja harusnya lebih fokus pada perkembangan pengetahuan dan peningkatan kecerdarasan. Hal itu terdapat pada kalimat "Bila terus dituruti kemauan dan nafsu, justru aku kehilangan kesempatan dan memusatkan diri pada pelajaran yang kelak akan merugikan diriku sendiri" bentuk moral tersebut disampaikan langsung melalui tokoh Rafa. Bentuk penyampaian langsung dipilih Nur agar pembaca mudah memahami bagaimana maksud dari sikap Rafa dalam novel tersebut. Pada kalimat "Itu pula sebabnya sampai sekarang aku tidak lagi memikirkan tentang urusan perempuan, dan lebih suka memilih menenggelamkan diri dalam buku bacaan." Nur menyampaikan uraiannya secara langsung. Moral yang disampaikan merupakan hal positif yang dilakukan oleh Rafa. Bentuk penyampaian tersebut terlihat jelas pada penggalan kalimat di atas, oleh sebab itu pembaca langsung dapat memahami moral yang Nur sampaikan dalam novelnya.

"Paling-paling aku mengulang-ngulang

pelajaran, membaca-baca buku pelajaran" (Nur, 2017: 41)

Pesan yang disampaikan pengarang dalam kutipan tersebut merupakan bentuk penyampaian langsung. Rafa memang suka membaca buku, hal tersebut bisa dijadikan contoh untuk remaja jaman sekarang. Dalam novel ini Nur banyak sekali menyampaikan moral salah satunya melalui tokoh. Tokoh yang digambarkan dalam novel ini begitu suka terhadap buku, membaca dan rajin dalam belajar salah satu tokoh tersebut yaitu Rafa. Kutipan di atas juga berupa bentuk penyampaian langsung yang disampaikan langsung melalui tokoh. Nur juga membahas tentang perang Aceh yang dulunya terjadi pada tahun 90-an yang menelan begitu banyak korban jiwa salah satunya seperti kutipan berikut.

Aku tidak tahu apa-apa tentang perang Aceh, meskipun aku lahir di saat kecamuk perang sedang berlangsung, aku lahir tahun 1994, dan tidak lama berselang kelahiranku terjadilah pembunuhan, pembantaian penduduk, penculikan, pemerkosaan, pembakaran rumah penduduk, penghancuran gedung sekolah, perusakan gedung perkantoran, penembakan dan penganiayaan yang tiada habisnya, yang terjadi 
dimana-mana.

Membayangkannya saja

cukup mengerikan. Namun

aku memang tidak tahu

apa-apa tentang perang

karna pada saat itu aku

masih kanak-kanak. (Nur,

2017: 34)

Kutipan di atas mengandung pesan moral berupa perang Aceh yang terjadi sangat memberikan dampak buruk bagi masyarakat Aceh. Moral di atas disampaikan melalui tokoh, moral tersebut ditujukan kepada pembaca, bukan untuk tokoh dalam novel tersebut. Nur menggunakan bentuk penyampaian langsung. Nur menyampaikan pesan moralnya melalui kutipan di atas sehingga secara langsung pembaca dapat memahami pesan yang disampaikan Nur pada kutipan di atas.

Setiap orang tua pasti menginginkan yang terbaik untuk anaknya, apalagi bagi seorang muslim, tentu dia ingin anaknya beriman. Tidak hanya mengantar ke sekolah, tetapi juga mengaji. Begitulah moral yang disampaikan oleh pengarang melalui karyanya. Kutipan tersebut dapat dilihat seperti di bawah ini.

Lantaran orang tuaku
termasuk taat agama,
merekapun
mengantarkanku ketempat
pengajian pada sore hari.
Ketika tumbuh remaja, aku
pergi ke balai pengajian
terdekat pada malam hari,
belajar membaca Alquran
dengan tajwid yang benar,
disamping belajar
memahamir kandungan
kitab kuning bersama
belasan anak lain. (Nur,
2017: 47)

Kutipan di atas adalah bentuk penyampaian langsung yang digunakan Nur untuk pembaca agar mendidik anak dengan benar. Pada kutipan di atas juga menjelaskan bahwa pada malam hari Rafa belajar membaca Alquran dengan tajwid. Hal itu merupakan moral yang disampaikan oleh pengarang melalui tokoh Rafa sebagai tokoh utama dalam novel Bulan Kertas. Kutipan di atas sampaikan untuk pembaca terlebih untuk ibu-ibu di luar sana.

Dalam novel ini Nur juga memaparkan nilai moral melalui Rafa yang berkaitan dengan membaca buku salah satu cara melawan bosan. Berhubung Rafa suka membaca buku maka banyak moral yang dapat disampaikan Nur melalui tokoh Rafa. Berikut kutipan di bawah ini.

Namun, aku lebih sering melawan kebosanan dengan membaca buku, karena menonton film hanya akan menatangkan kehampaan belaka. Membaca buku, meski cuma sebuah novel, bisa membuat perasaanku lega. Bila kupikir-pikir, peningkatan kualitas seseorang bukan karena pelajaran sekolah. Kemampuan berpikirku, ditambah sedikit kebijaksanaan, bukanlah kudapkan dari pendidikan sekolah, melainkan dari membaca buku. (Nur, 2017: 56-57)

Nur menggunakan bentuk penyampaian langsung untuk memaparkan berkembangnya pemikiran seseorang bukanlah dari pengetahuan di sekolah, melainkan dari membaca buku. Melalui kutipan di atas sehingga pembaca secara langsung dapat memahami bagaimana apa yang pengarang sampaikan. Pada kalimat "Kemampuan berpikirku, ditambah sedikit kebijaksanaan, bukanlah kudapkan dari pendidikan sekolah, melainkan dari membaca buku." Adalah moral yang disampaikan oleh Nur melalui tokoh Rafa yang memberikan motivasi kepada pembaca. Motivasi yang disampaikan Nur 
melalui tokoh Rafa bersifat langsung. Membaca buku merupakan hal yang mudah dilakukan, hanya saja sebagian orang merasa malas untuk melakukannya, tetapi berbeda dengan tokoh dalam novel ini. Rafa merupakan tokoh utama dalam novel dan Rafa juga suka membaca. Hal itu dapat dilihat pada kutipan berikut.

Membaca buku, bila sudah
dir mulai, akan
mengasyikkan sekali.
Ketika aku tenggelam di
dalamnya, semua dunia
berubah seketika, dan untuk
sejenak aku lupa pada
segala masalah yang
sedang kuhadapi. (Nur,
2017: 56-57)

Pada kutipan di atas Nur juga menyampaikan moralnya secara langsung melalui uraian pengarang. Pada kalimat "Membaca buku, bila sudah di mulai, akan mengasyikkan sekali." Nur menyampaikan moralnya berupa pentingnya membaca buku. Bahkan dengan membaca buku bukan hanya ilmu yang bertambah tetapi juga wawasan kita menjadi luas. Penggalan kalimat di atas merupakan bentuk penyampaian secara langsung, moral yang disampaikan kepada pembaca berupa membaca bukanlah sesuatu yang rumit hanya saja sedikit rasa malas untuk memulainya. Berbeda dengan tokoh dalam novel ini, di sini Nur menunjukkan sikap yang patut dicontoh untuk remaja-remaja lainnya. Seperti pada kutipan di bawah ini.

Sebelum pamit, kami
sempat
memperbincangkan
perihal novel, sesuatu
yang masihasing dan tidak
disukai orang. "Suatu hari
nanti aku akan menulis
novel," kata Naya, yang
membuat aku
terperangah." Tapi, aku
tidak terlalu yakin."
"aku yakin, dan kau pasti
(Nur, 2017: 84)

Dalam kutipan di atas kita dapat melihat penyampaian yang diuraikan pengarang pada kalimat "Sebelum pamit, kami sempat memperbincangkan perihal novel, sesuatu yang masih asing dan tidak disukai orang." Kalimat tersebut merupakan moral yang disampaikan pengarang secara langsung, Nur menyampaikan moral berupa kegemarannya dengan pembaca. Bentuk penyampaian moral di atas digambarkan tokoh Naya adalah seorang remaja yang suka membaca, walaupu hal itu masih menjadi sesuatu yang tidak disukai orang.

Rafa tidak membalas kejahatan yang telah Askan lakukan padanya, biarlah Tuhan yang membalasnya. Begitu yang Rafa pikirkan. Rafa memang tidak terbiasa yang membalas kejahatan dengan kejahatan, walaupun sekarang ia berniat membalas dendam terhadap Askan. Namun, ia mengurungkan niatnya dan hilang semangat saat ingin membalas perbuatan jahat yang Askan lakukan padanya. Hal itu bisa dilihat pada kutipan di bawah berikut.

"Tiba-tiba aku kehilangan
semangat dan pikiranku
berubah drastis. Sangat
tiba-tiba dan ada yang
berbisik dalam benakku:
Biarlah Tuhan saja yang
membalasnya, batinku
dengan langkah mantap
meinggalkan tempat itu."

(Nur, 2017: 95)

Peristiwa di atas menunjukkan sifat Rafa yang sebenarnya lemah, tidak berani melawan. Hal itu tidak di jelaskan secara langsung dalam peristiwa di atas karena kutipan tersebut bersifat bentuk penyampaian tidak langsung. Perbuatan seperti itu biarlah Tuhan yang membalasnya dan rencana Tuhan jauh lebih baik. Benar saja, saat Rafa dan Naya berjalan hendak pulang karena kegiatan sekolah sudah berakhir mereka melihat Askan menendang ban keretanya karena bocor. 
Ibu Naya adalah seseorang yang paham bagaimana kondisi Naya saat ini. Setelah meniggalnya Nadira, mereka kembali ke kampung halamannya di kota Takengon, Aceh. Pada saat itu yang membuat Rafa frustasi akibat hilangnya jejak Naya sampai akhirnya mereka kembali bertemu di kampus yang sama. Ibu Naya merupakan tokoh tambahan dalam novel Bulan Kertas. Bentuk penyampaian moral secara langsung juga Nur sampaikan melalui tokoh ibu Naya. Orang tua juga banyak memberikan moral terhadap pembaca, ketika Rafa menyusul Naya ke sana yang disambut dengan senang hati oleh Ibunya Naya. Hal tersebut bisa dilihat pada kutipan di bawah ini.

"Oh, anakku yang hilang,
sekarang kau sudah
kembali. Masuklah. Ini
kejutan. Lama sekali aku
tidak melihat mu. Oh,
banyak sekali yang sudah
terjadi dua tahun ini. Kau
haus? Mau minum apa?"

(Nur, 2017: 203)

Pada kutipan di atas bisa dilihat cara ibu Naya yang menyambut tamu, ibu Naya yang juga merupakan tokoh dalam novel tersebut. Namun, pengarang menyampaikan moral secara langsung melalui tokoh ibu Naya. Bentuk penyampaian langsung yang digunakan Nur dalam novelnya agar pembaca dapat memahami moral yang Nur sampaikan melalui tokoh. Bentuk penyampaian moral yang digunakan Nur pada ibu Naya dapat dilihat ketika ibu Naya menyambut Rafa sebagai tamu. Seperti pada kalimat "Oh, banyak sekali yang sudah terjadi dua tahun ini. Kau haus? Mau minum apa?" merupakan basa-basi yang dilakukan ketika tamu datang. Bukan berarti tamu harus bersikap sesukanya tetapi kita sebagai tuan rumah harus melayani dengan baik terhadap tamu yang datang. Tamu tidak setiap hari datang, sebab itulah kita harus melayaninya dengan baik.
Rafa sudah sangat lama berteman dengan Naya. Ketika ibu Naya melihat sikap Rafa terhadap anaknya, mungkin sebab itulah ibu Naya merasa bahwa Rafa benar-benar tulus berteman dengan Naya. sehingga ibu Naya menganggap Rafa sebagai salah satu anggota keluarganya. Seperti pada kutipan tersebut.

"Beginilah keadaan kami setelah Nadira meningggal"

"Tapi, aku senang sekali

Nak Rafa datang. Kami

sudah menganggapmu

seperti saudara. Terlebih

lagi setelah Nadira pergi."

(Nur, 2017: 210)

Begitulah ibu Naya terhadap Rafa. Ia senang jika Rafa berteman dengan Naya karena setelah Nadira meninggal Rafalah yang ada untuk Naya, menghibur Naya, mengisi hari-harinya yang begitu sunyi. Kalimat "Tapi, aku senang sekali Nak Rafa datang. Kami sudah menganggapmu seperti saudara. Terlebih lagi setelah Nadira pergi." Dapat dilihat moral yang disampaikan secara langsung oleh Nur. Ibu Naya sudah menganggap Rafa seperti saudaranya sendiri. Sebelum Nadira meninggal, Naya sudah merasa kesepian, merasa sendiri, bahkan hanyut dalam dunianya sendiri. Perihal dunia lain yang sudah melekat dalam tubuhnya. Soal mimpi-mimpi yang aneh yang membuat Naya merasa bahwa ia hidup sendirian. Terlebih setelah Nadira meninggal. Tak dapat dipungkiri, Naya benar-benar kesepian.

Nafil merupakan tokoh tamhaban yang digunakan pengarang dalam novelnya. Nafil merupakan salah satu teman kelas Rafa, Nur juga menyampaikan moral melalui tokoh Nafil. Salah satu bentuk moral bisa berupa perhatian seseorang terhadap temannya. Hal tersebut menandakan kepedulianm seseorang, seperti yang pengarang ciptakan dalam novel Bulan Kertas. Berikut kuytipan mengenai perhatian seorang teman. 
"Tapi, benar, wajahmu tampak kusut," kata Nafil

"Ada masalah apa?"

"tidak ada apa-apa," balasku kurang acuh.

"cerita saja. Tak usah malu. Kau ini pendiam dan tertutup sekali," ucapnya hati-hati seraya memerhatikanku agak lekat. "kalau dipendam sendiri, bakal jadi beban!"

(Nur, 2017: 21)

Berdasarkan dialog di atas dapat diketahui bahwa Nafil adalah teman yang peduli. Pada kalimat "cerita saja. Tak usah malu. Kau ini pendiam dan tertutup sekali, ucapnya hati-hati seraya memerhatikanku agak lekat. kalau dipendam sendiri, bakal jadi beban!" adalah bentuk kepedulian seorang teman. Ketika Nafil melihat perubahan ekspresi Rafa, Nafil langsung menanyakan masalah yang sedang dialaminya. Namun, karena Rafa seseorang yang pemalu dan pendiam dia lebih memilih menghindar dari temannya tersebut. Kutipan di atas menunjukkan nilai moral yang disampaikan Nur secara langsung melalui tokoh Nafil. Bentuk penyampaian moral yang disampaikan pengarang melalui tokoh Nafil berupa sikap kepedulian terhadap Nafil salah satu teman kelas Rafa.

\section{b. Bentuk Penyampaian Tidak Langsung}

\section{Melalui Peristiwa}

Melalui peristiwa, Nur menyampaikan moralnya secara tidak langsung. Salah satu sifat khas karya sastra adalah berusaha mengungkapkan sesuatu secara tidak langsung. Ketika Rafa bersyukur karena tidak jadi membalas kejahatan yang Askan lakukan padanya. Hal itu bisa dilihat pada kutipan di bawah.

"Aku bersyukur karena
tidak jadi membalas
kedengkian dan kejahatan
Askan dengan kejahatan

pula. Namun, siapakah orang yang melakukannya? Aku terheran-heran dan tertegun-tegun sendiri sambil terus melangkah di sisi Naya. sementara wajah gadis itu tampak cerah bercahaya, tersenyum-senyum sendiri; senyuman yang tak biasa, dan sulit kupahami." (Nur, 2017: 95)

Ucapan dari Rafa dapat membuat pembaca mengetahui sifat Rafa walaupun 1tidak dijelaskan secara langsung. Pada dialog "Aku bersyukur karena tidak jadi membalas Skedengkian dan kejahatan Askan dengan kejahatan pula." Pada dialog tersebut dapat diketahui bahwa Rafa salah satu tokoh yang baik, sehingga Rafa tidak perlu membalas kejahatan yang Askan lakukan terhadapnya. Selain kutipan di atas, Naya juga menceritakan sekilas mengenai dunia lain. Hal itu dapat dilihat pada kutipan di bawah ini.

"Sepertinya sebelum aku masuk SD. Aku ingat, saat mimpi pertama tentang dunia lain itu, aku terbangun tengah malam. Seluruh tubuh dan jiwaku seperti hancur, lebur. Aku menangis seorang diri. Hanya seorang diri. Tak ada orang yang menolongku. Ayah dan Ibu terlelap di ranjang sebelah. Berkali-kali aku hendak

membangunkannya, tapi batal. Aku hanya menangis, menangis seorang diri, tanpa mengerti apa yang sedang terjadi , tanpa tahu apa yang sedang kutangisi. Yang kurasakan dunia ini sunyi sekali. Sunyi yang 
begitu hebatnya." (Nur,

2017: 114)

Kutipan di atas adalah peristiwa yang Naya alami, disebabkan peristiwa tersebut sikap Naya sekarang yang sulit ditebak, Naya yang hanyut dalam dunianya sendiri bahkan kadang-kadang bersifat ganjil. Peristiwa yang Naya alami tiak dijelaskan secara langsung bahwa peristiwa itu ada keterkaitannya dengan dunia lain yang sampai sekarang masih melekat pada dirinya. Karena pada peristiwa di atas Nur menggunakan bentuk penyampaian tidak langsung.

Sifat seperti itu hanya Rafa yang tahu karena Rafa satu-satunya teman dekat Naya. Walaupun Naya sempat mengeluh dengan peristiwa ganjil yang dialaminya, tetapi Naya sering tenggelam saat membaca, maupun itu novel atau buku-buku bacaan lainnya. Disebabkan peristiwa tersebut Naya memberikan nilai moral bagi pembaca meskipun sesekali Naya menunjukkan sikapnya yang kurang wajar.

"Berselang tiga bulan

kemudian aku menerima kabar bahwa Naya ditemukan tewas, tubuhnya tersangkut di pohon kayu di dasar jurang bukit yang pernah dua kali aku kunjungi bersamanya. Ibu Naya menghubungiku lewat telepon genggam dan dua hari setelah kejadian itu, karena dia kesulitan menemukan namaku yang disimpan di telepon genggamnya."

(Nur, 2017: 219)

Kutipan di atas menunjukkan cara pengarang menyampaikan peristiwa yang menimpa Naya. kalimat "Berselang tiga bulan kemudian aku menerima kabar bahwa Naya ditemukan tewas," merupakan moral yang disampaikan melalui peristiwa yang dialami Naya. moral tersebut disampaikan secara tidak langsung. Pada waktu tertentu Naya seolah memperlihat kepada Rafa bagaimana yang ia rasakan. Seperti pada kutipan di bawah.

"Sekarang Naya sudah pergi. Memang sedari dulu dia sudah pergi. Sedari awal dia sudah tersesat dalam dunianya sendiri; dunia lain, dan dia tidak pernah bisa keluar." (Nur, 2017: 220)

Begitu yang Rafa katakan seolah dia juga merasakan sekilas apa yang Naya rasakan. Namun, ia tidak pernah berpikir kalau Naya akan berbuat sejauh ini. Di luar dugaan semua orang, dan semua pertanyaan yang terlintas di benaknya juga sudah tidak perlu ditanyakan lagi. Pada dialog "Memang sedari dulu dia sudah pergi", dapat diketahui bahwa penyebab kematian Naya dikarenakan dunia lain yang dimaksudkan oleh Naya sendiri dan hanya Naya yang paham mengenai dunia lain tersebut. Hal itu tidak dijelaskan secara langsung oleh Nur karena Nur menggunakan bentuk penyampaian tidak langsung. Bentuk penyampaian tidak langsung lainnya juga disampaikan oleh Nur seperti pada kutipan di bawah ini.

"Kenapa Naya bisa
begitu? Kenapa dia
sampai jatuh ke jurang?
Sekarang semuanya tak
perlu dipertanyakan lagi.
Apapun penjelasannya
sudak tidak berguna. Dia
sudah mati dan
dikuburkan. Begitulah...."

(Nur, 2017: 220)

Pada kutipan di atas secara tidak langsung dijelaskan bahwa Rafa yang mengikhlaskan kepergian Naya. Walaupun Rafa tegar, dan mengikhlaskan kepergian Naya teman dekatnya tetapi sedikit rasa kehilangan itu sudah pasti ada dalam diri Rafa. Gadis yang sempat membuat Rafa merasa frustasi saat tibatiba ia hilang tanpa kabar begitu saja, sekarang sudah tinggal kenangan. Hanya 
itu yang tersisa dan sebuah novel yang Naya tulis untuk Rafa kemudian dititipkan pada ibunya untuk diberikan kepada Rafa, novel itu satu-satunya bagian dari Naya. Setelah hari ketujuh Naya meninggal Rafa kembali ke Banda. Di sana ia membuka kotak pemberian Naya. seperti pada kutipan di bawah ini.

"Setibanya di Banda, aku menemui kamar kost yang juga begitu sunyi. Entak kemana perginya Kanafi. Dalam kemuraman kamar, perlahan-lahan aku membuka kotak pemberian perempuan yang sudag tiada itu. Sepertinya sudah sejak lama ia mempersiapkan ini." (Nur, 2017: 221)

\section{Melalui Konflik}

Dalam menyampaikan moral secara tidak langsung, pengarang menyampaikan pesan moralnya melalui konflik antar tokoh. Konflik ini dapat dilihat pada kutipan berikut.

"Bagaimana kalau aku mengganti makananmu yang tumpah itu?”

"Ah, tidak perlu."

"Kenapa?" lapar."

"Karena aku memang tidak

"Meski aku tidak sengaja tapi aku tetap merasa bersalah,"

"Jangan terlalu dipikirkan." (Nur, 2017: 14)

Konflik antar tokoh yang disampaikan pengarang tersebut konflik antara Naya dan Rafa. Pada dialog di atas tidak terlihat secara langsung bagaimana sifat Rafa saat Naya menumpahkan makanannya. Pada kalimat "Bagaimana kalau aku mengganti makananmu yang tumpah itu? " terdapat pesan moral yang tersirat pada kalimat tersebut. Naya ingin menggantikan makanan Rafa yang telah ditumpahkan karena Naya merasa bersalah walaupun hal itu tidak disengaja. Moral tersebut disampaikan secara tidak langsung melalui konflik yang terjadi dalam novel Bulan Kertas. Konflik batin lainnya dapat dilihat pada kutipan berikut. "Aku mengutuki kemalangan diri sendiri yang sulit bergaul, terlebih dengan teman perempuan. Karenanya pula, setiap kali menyukai seorang gadis, aku tidak berani mendekatinya, apalagi mengajaknya bicara. Aku ini memang pengecut, lebih suka memendam perasaan dan mencintai seseorang secara diamdiam." (Nur, 2017: 18)

Moral yang terdapat dalam konflik tersebut berupa konflik batin. Hal itu dapat dilihat pada kalimat " $A k u$ ini memang pengecut, lebih suka memendam perasaan dan mencintai seseorang secara diam-diam." Merupakan moral yang disampaikan secara tidak langsung oleh pengarang melalui konflik di atas. Konflik di atas merupakan bentuk penyampaian moral secara tidak langsung yang diciptakan Nur dalam novel Bulan Kertas. Itulah moral yang Nur ciptakan dalam novelnya, walaupun kadang-kadang tidak dijelaskan secara langsung sifat Rafa yang mengutuki dirinya sendiri disebabkan sifat minder yang ia alami. Konflik batin lainnya seperti kutipan di bawah ini.

"Yang penting bagiku saat

ini adalah kisah dalam buku itu bisa jadi pelipur lara, aku ingin masuk ke dalam novel itu dan menjadi tokoh utamanya. Bila saja mungkin, aku ingin tetap tinggal di dalamnya sehingga aku tidak perlu lagi berjumpa dengan Naya selamanya."

(Nur,2017: 31)

Itulah yang Rafa lakukan ketika ingin menghindar dari Naya, karena ia berpikir banyak laki-laki yang mengincar Naya. kalimat "Yang penting bagiku saat ini adalah kisah dalam buku itu bisa jadi 
pelipur lara," salah satu bentuk penyampaian moral secara tidak langsung berupa konflik. Moral pada penggalan kalimat di atas berupa melampiaskan rasa kecewanya terhadap buku. Namun moral tersebut tersirat karena pengarang menyampaikan melalui konflik yang berupa bentuk penyampaian tidak langsung. Nur menggunakan bentuk tersebut agar pembaca lebih menafsirkan kutipan-kutipan yang terdapat dalam novel Arafar Nur.

"Kau sudah terlalu sering meningggalkan pengajian.

Kenapa akhir-akhir ini kau menjadi begitu malas?"

"Aku mengaji dirumah, $B u$,"

"Ibu tahu,"

"Tapi masih banyak yang perlu kau pelajari di balai"

"Pengajian di balai terlalu lama selesai, Bu," "Aku juga punya banyak tugas sekolah. Lagi pula mulai sekarang aku harus siap-siap menghadapi Ujian Nasional. Aku sudah kelas tiga."

"Kalau memang untuk belajar tidak mengapa,"

"Yang jangan, kau keluyuran malam." (Nur, 2017: 61-62)

Konflik pada dialog di atas berupa bentuk penyampaian secara tidak langsung, pada dialog di atas tidak dijelaskan secara langsung moral yang terdapat dalam dialog tersebut, moral yang disampaikan oleh ibu Rafa menasehati dalam kebenaran, Rafa yang menyikapi sikap ibunya yang menasehati dibalas dengan anggukan dan sedikit membela diri. Bahwa ia tidak mengaji di balai dikarenakan harus belajar karena sebentar lagi Ujian Nasional akan berlangsung.

Naya yang dikenal sebagai seseorang yang lemah dikarenakan penyakit aneh yang dialaminya. Bahkan ia sulit menjelaskan bagaimana yang Naya rasakan. Bentuk penyampaian tidak langsung ini diterapkan oleh pengarang dalam novelnya karena dalam novel tersebut terdapat banyak sekali peristiwa atau konflik yang merupakan bentuk penyampaian tidak langsung. Pada saat Rafa berpikir bagaimana yang dimaksudkan Naya dengan dunia lain itu, konflik batinpun terjadi saat Rafa berusaha mengingat-ingat tentang penyakit yang dialami oleh Naya. Hal itu dapat dilihat dari kutipat tersebut.

"Saatr mengucapkan
beberapa patah kata
terakhir, bibir Naya
bergetar. Berkali-kali dia
berusaha mengucapkan
sesuatu, tetapi tidak ada
suara yang keluar. Naya
menundukkan wajahnya
yang mulai pucat dan
kuyu.
Tentu saja kau tidak
mengerti. Apakah dunia
lain yang dimaksudkan
Naya itu? Kenapa dunia
aneh itu membuat hidup
Naya tertekan? Bukankah
itu hanya mimpi, kenapa
terlalu dipikirkan? Aku
ingin bertanya demikian,
tetapi khawatir
membuatnya
tersinggung." (Nur, 2017:
113)
Rafa begitu peduli tehadap

Rafa begitu peduli tehadap Naya, konflik batin tersebut tidak dijelaskan secara langsung bahwa Rafa peduli pada Naya. Kalimat "Apakah dunia lain yang dimaksudkan Naya itu? Kenapa dunia aneh itu membuat hidup Naya tertekan? Bukankah itu hanya mimpi, kenapa terlalu dipikirkan? Aku ingin bertanya demikian, tetapi khawatir membuatnya tersinggung." Pada kalimat tersebut Nur menyampaikan moralnya melalui konflik batin yang dialami oleh tokoh. Namun, tidak dijelaskan secara langsung bagaimana yang dikatakan Rafa bahwa ia 
peduli terhadap Naya karena pada kutipan di atas Nur menggunakan bentuk penyampaian tidak langsung.

Menjelang lebaran tiba kembali Rafa mengalami konflik batin saat malam takbiran. Rafa tidak habis-habisnya mengutuki dirinya sendiri sebagai lelaki pengecut. Hal itu bisa dilihat pada kutipan di bawah ini.

"Gema takbir yang
mengagungkan kebesaran
nama Tuhan itu sahut
menyahut tiada putus,
membuat bulu romaku
merinding.
merasakan, Aku
kekuasaan Allah itu Maha
Besar dan tidak ada
batasnya. Manusia
hanyalah makhluk fana
yang tidak berdaya.
Apalagi aku, laki-laki
pengecut dan pemalu yang
hanya untuk melindungi
diri sendiri saja tidak
mampu, rapalagi
melindungi reorang
gadis." (Nur, 2017: 117)

Konflik batin di atas berupa bentuk penyampaian tidak langsung karena Rafa lagi-lagi mengutuki dirinya. Rafa juga mengingat kebesaran Tuhan, saat menyambut hari kemenangan takbiran pun berkumandang dimanamana. Tidak terkecuali di kota maupun dikampung, saat itu kita bisa mengingat bahwa Tuhan selalu bersama kita, yang masih diberikan kesempatan untuk dapat berkumpul dengan keluarga tercinta pada hari kemenangan tersebut.

"Sepanjang malam aku menangis, mungkin juga dalam tidur. Sebentarsebentar mataku mengeluarkan air mata, bahkan ketika paginya kau terbangun; mataku dalam keadaan basah." (Nur, 2017: 138)
Konflik batin pada kutipan di atas berupa bentuk penyampaian tidak langsung karena tidak dijelaskan secara langsung kepedulian Rafa terhadap keluarga Naya yang sedang berduka, saat Nadira adiknya Naya meninggal dunia semua merasa kelihalangan. Terlebih itu Naya, selain ia mempunyai Rafa sebagai teman dekatnya, Nadira yang selalu bersamanya sekarang sudah tidak ada lagi. Rafa yang mengenalnya sekilas juga ikut berduka. Apalagi saat melihat kondisi Naya yang sangat terpukul dengan kehilangan adik satu-satunya membuat Rafa tidak tega meniggalkan Naya untuk pulang, karena itu Rafa memilih menetap sebentar sampai Naya tertidur pulas dalam pangkuannya.

"Tiba-tiba aku dirundung kesunyian yang hebatnya tiada tara, menyadari betapa fananya manusia ini; menyadari suatu ketika juga aku akan seperti itu; mati, terbujur kaku, dan dilupakan. Di tempat seperti ini jasadku dikuburkan, membusuk lalu sirna tanpa bentuk untuk selama-lamanya. Mungkin hanya beberapa orang saja yang akan mengingat dan mengenangku, itupun jika kelak aku punya anak cucu. Tidak lebih dari dua generasi, sebelum dunia melupakanku untuk selama-lamanya; ya, untuk selama-lamanya." (Nur, 2017: 139)

Bentuk penyampaian secara tidak langsung yang disampaikan pengarang melalui tokoh Rafa berupa konflik batin. Mengingat meninggalnya Nadira, Rafa tersadar jika semua manusia akan menyusulnya, manusia hidup sementara di dunia dan selama-selamanya di akhirat. Kita tidak selama-lamanya hidup dunia 
yang fana ini, sudah menjadi hukum alam bahwa yang bernyawa akan mati.

"Entah kenapa akhir-akhir ini aku semakin sulit mengungkapkan sesuatu. Aku ingin mengatakan ini, tapi justru maksudnya itu. Aku mengatakan itu, justru maksudnya ini. Apa yang kukatakan tidak sesuai dengan apa yang kumaksudkan, bahkan sering bertentangan. Pikiranku benar-benar kacau. Semua benang dalam kepalaku menjadi begitu kusut; kusut berantakan, dan sulit dirapikan. Kau paham kan?" (Nur, 2017: 144)

Konflik batin pada kutipan di atas disampaikan melalui tokoh Naya yang tidak dijelaskan secara langsung. Naya sempat mengeluh dan putus asa terhadap penyakitnya. Kalimat "Entah kenapa akhir-akhir ini aku semakin sulit mengungkapkan sesuatu. Aku ingin mengatakan ini, tapi justru maksudnya itu. Aku mengatakan itu, justru maksudnya ini." Merupakan salah satu konflik batin yang dialami Naya saat bersama Rafa. Konflik batin yang dialami Naya merupakan bentuk penyampaian secara tidak langsung, dalam konflik tersebut terdapat moral yang disampaikan pengarang bahwa Naya mencoba mengalihkan perhatian tentang penyakitnya dengan membaca buku, ia merasa lebih baik jika membaca.

"Kenapa dia hanya
menuliskan sebaris
kalimat yang begitu
singkat? Tiba-tiba aku
kesal sendiri; resah tak
menentu. Apa yang telah
terjadi dengan Naya?
apakah dia tidak
mencintaiku? Kenapa dia
begitu menyiksaku? Oh,
Naya, aku menderita

karenamu. Aku menderita sekali...." (Nur, 2017: 156157)

"Andai saja dia menyimpan sedikit perasaanya padaku, tentu dia tidak akan meninggalkanku begitu saja. Separah apapun, dia akan kembali untuk menemuiku, setidaknya ada meniggalkan jejak. Namun, kenyataannya, dia pergi begitu saja dariku dengan hanya meniggalkan sebuah baju dengan secarik kertas bertuliskan sebaris kalimat pendek-Aku ingin kau selalu mengingatku, Rafayang sangat menyiksaku. Apa arti semua ini? Tanpa diminta mengingatnya, akupun akan tetap mengingatnya. Semisal pun dia melarangku, aku tetap tidak bisa melupakannya." (Nur, 2017: 168)

Konflik batin yang dirasakan oleh Rafa begitu menyiksa, walaupun tidak dijelaskan secara langsung, berkali-kali ia mengingat Naya. Naya menghilang begitu saja tanpa kabar apapun, tanpa permisi terlebih dahulu. Moral dalam konflik batin di atas yaitu kesabaran Rafa yang tidak dijelaskan secara langsung juga saat menuggu Naya kembali. Naya yang selalu menghilang kemudian kembali lagi dengan merasa bersalah karena telah membuat Rafa menderita karenanya dan membuat Rafa frustasi.

Setelah lama hilangnya Naya, kemudian ia kembali lagi dan bertemu di kampus yang sama. Mereka sama-sama menjadi mahasiswa disalah satu kampus di Banda Aceh. Tanpa kesengajaan mereka juga memilih jurusan yang sama dan sebelumnya mereka tidak pernah bertemu di kampus saat sedang 
berlangsungnya mata kuliah masingmasing. Sejujurnya Rafa merasa kecewa terhadap Naya yang pergi begitu saja meniggalkannya. Hal itu dapat dilihat pada kutipan tersebut. juga.” "Itu demi kebaikan kita

"Kebaikan kita

bagaimana? Apakah kau tidak tahu bagaimana perasaanku?" hanya....?" "Aku tahu, Rafa. Aku

"Kau seperti orang tidak punya perasaan."

"Aku hanya tidak ingin kau

lebih terluka."

"Nyatanya aku terluka," "Kenapa aku begitu sulit memahamimu?"

"itulah masalahnya!"
"Maafkan aku, Rafa,"
"Aku kesulitan
menjelaskan semuanya.

Tapi, perlu kau tahu, Rafa,

aku begitu sayang

padamu...." "Maafkan aku

ya?" (Nur, 2017: 180-181)

Konflik di atas merupakan konflik antar tokoh, pemyampaian moral secara tidak langsung tersebut yaitu berani bertanggung jawab atas kesalahan yang sudah di perbuat. Naya sudah membuat kesalahan besar karena meniggalkan Rafa tanpa kabar sedikit pun. Sudah pasti Rafa akan mencarinya kesana kemari, kemudian Naya meminta maaf atas apa yang telah dilakukannya. Memang bukan sengaja Naya meniggalkan Rafa, tetapi setidaknya Naya memberikan kabar atau petunjuk bagi Rafa. Pentingnya menyampaikan bentuk penyampaian tidak langsung dalam novel, agar pembaca lebih menafsirkan apa yang dimaksudkan oleh pengarang.

"Seperti sudah-sudah, Naya pergi tanpa meniggalkan sebaris pesan pun sehingga aku terus uring-uringan. Panik, kesal, resah, kecewa, gemas, bercampur-baur, hingga akhirnya aku mendongkol sendiri. Segala pertanyaan berkemcamuk; apakah dia ditabrak, mati jatuh ke sungai, atau bagaimana. Sama sekali tidak bisa menghubunginya karena dia tidak memakai telepon genggam. Akhirnya aku hanya bisa pasrah, menuggu-nunggu sesuatu. Sesuatu yang tidak kutahu, bisa juga berita mengenai dirinya yang entah lewat mana, mungkin juga lewat surat kabar."

(Nur, 2017: 195)

Konflik batin di atas terjadi ketika Naya lagi-lagi menghilang setelah belum lama mereka bertemu kembali. Hal itu membuat Rafa begitu geram dibuatnya. Kutipan di atas yaitu seperti kutipan sebelumnya, juga tidak dijelaskan secara langsung kesabaran Rafa terhadap Naya begitu besar. Diam-diam sudah sejak lama ia menaruh hati kepada Naya. Namun, hal itu tidak diungkapkan langsung oleh Rafa, karena Rafa seorang pendiam dan pemalu. Terlebih lagi dengan seorang gadis.

"Rafa, kelihatannya ada sesuatu yang tidak beres denganmu"

"Memangnya, apa ada yang beres dengan dunia ini?"

"Aku mulai cemas dengan keadaanmu dan kuliah mu,"

"Percayalah, selama aku masih hidup, tidak ada yang perlu dicemaskan."

"Sudah beberapa hari ini aku tidak melihat pacarmu yang cantik itu."

"Aku juga tidak."

"Memangnya dia kemana?"

"Kalau aku tahu, pasti aku sudah menemuinya."

"Dia hilang?"

"Ya, hilang," "Dia selalu hilang."

"Dia selalu hilang?" "Aku tidak mengerti." 
"Kalau kujelaskan pun kau tidak akan mengerti."

"Oh," (Nur, 2017: 198-199)

Pada kutipan di atas terjadi konflik antar tokoh. Bentuk penyampaian secara tidak langsung dijelaskan yaitu kepedulian seorang teman ketika keadaan Rafa semakin tak menentu. Kekhawatiran yang dirasakan Kanafi teman kos Rafa yang kerap melihat Rafa sering libur kuliah, dan melihat kelainan sikap dari sikap Rafa dari biasanya. Berselang tiga hari setelah seorang teman kos Naya memberikan sebuah alamat yang Naya titipkan, Rafa langsung menuju ke alamat yang terdapat pada surat tersebut. Seperti pada kutipan di bawah ini.

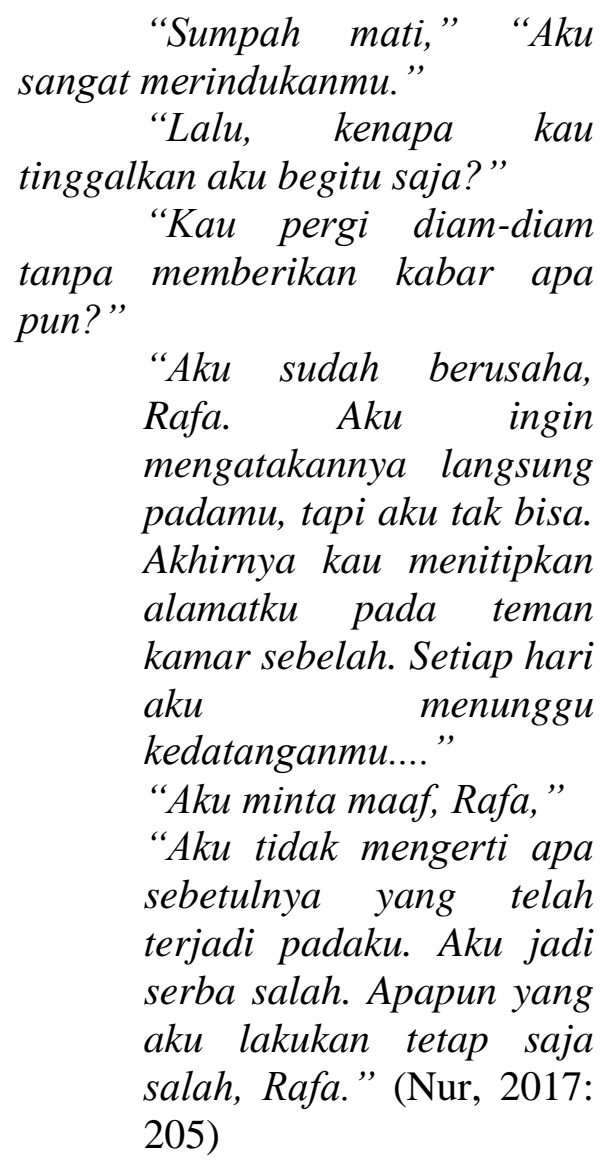

Kutipan di atas merupakan konflik antar tokoh. Moral pada kutipan di atas yaitu ketika Rafa memperjuangkan cintanya kepada Naya, ia rela datang jauhjauh dari Banda ke Takengon, kota kelahiran Naya. Rafa tidak peduli ujian final semester ganjil yang akan berlangsung beberapa hari lagi. Rafa hanya memikirkan Naya, mungkin tanpa
Naya hidupnya tidak akan bermakna. Kehadiran Naya lah yang banyak mengubah masa remaja Rafa dan lebih berarti.

Berselang tiga bulan kemudian terakhir Rafa bertemu dengan Naya, Rafa mendapat kabar bahwa Naya ditemukan tewas, tubuhnya tersangkut di atas pohon kayu besar di dasar bukit yang pernah ia kunjungi bersama Naya. Peristiwa itu membuat Rafa tersadar bahwa Naya tidak pernah mencintainya. Rafa begitu terpukul saat mendapat kabar seperti itu. Rafa hanya bisa mengikhlaskan kepergian Naya. Hal itu dapat dilihat dari kutipan tersebut.

"Kenapa Naya bisa tidak ada lagi? Dulu dia ada, sekarang tidak ada. Kenapa bisa tidak ada? Ternyata batas antara ada dan tiada itu tipis sekali. Kalau dipikir-pikir, hidupku ini juga berada diantara angan-angan dan kekosongan, tak ubahnya serupa bulan kertas. Sekarang Naya sudah pergi. Memang sedari dulu dia sudah pergi. Sedari awal dia sudah tersesat dalam dunianya sendiri; dunia lain, dan dia tidak pernah bisa keluar." (Nur, 2017: 220)

Kutipan di atas merupakan konflik batin yang disampaikan pengarang melalui bentuk penyampaian tidak langsung. Moral dalam kutipan di atas yaitu mengikhlaskan seseorang yang telah pergi. Sudah kehendak yang di atas mengatur hidup mati manusia. Kita hanya bisa pasrah dan menerima takdir yang telah ditentukan. Pada hari ketujuh meninggalnya Naya, Rafa hendak kembali ke Banda. Sebelum berangkat ibu Naya memberikan sebuah benda yang terbungkus kertas biru, di dalamnya terdapat buku tulis tebal bersampul biru cerah yang bertuliskan Pelangi Malam. 


\section{PENUTUP}

Berdasarkan hasil penelitian ada dua bentuk penyampaian moral yaitu bentuk penyampaian langsung dan tidak langsung. Keduanya diterapkan langsung oleh Arafat Nur dalam novelnya yang berjudul Bulan Kertas. Bentuk penyampaian langsung memiliki dua bentuk yaitu uraian pengarang dan melalui tokoh, sedangkan bentuk penyampaian tidak langsung memiliki bentuk penyampaian berupa peristiwa dan konflik. Bentuk penyampaian yang paling banyak terdapat dalam novel Bulan Kertas yaitu bentuk penyampaian konflik yang merupakan bentuk penyampaian secara tidak langsung. Dalam novel Bulan Kertas pengarang menggunakan semua bagian yang terdapat dalam bentuk penyampaian langsung dan tidak langsung yang menghasilkan data sebanyak 44 data. Dari penelitian yang dilakukan terhadap bentuk penyampaian moral dalam novel Bulan Kertas, maka disimpulkan bahwa bentuk penyampaian langsung berupa uraian pengarang terdapat 5 data, sedangkan melalui tokoh terdapat 18 data. Kemudian, data bentuk penyampaian tidak langsung berupa peristiwa terdapat 6 data dan berupa konflik terdapat 15 data.

\section{DAFTAR PUSTAKA}

Editorial, Padi. (2013). Kumpulan Super Lengkap Sastra Indonesia: Puisi, Pribahasa, Pantun, Majas, Profil Sastrawan. Jakarta: Raja Grafindo Persada.

Januarini, Windri Septi. (2013). Nilai Moral dalam Novel Tetralogi Laskar Pelangi Karya Andre Hirata. Skripsi tidak diterbitkan. Malang: Universitas Muhammaddiyah Malang
Kosasih. (2012). Dasar-Dasar Keterampilan Bersastra. Bandung: Yharma widya.

Kurniadi, Aluisius Titus. (2019). Analisis Nilai Moral dan Nilai Sosial Dalam Novel Daun Yang Jatuh Tak Pernah Membenci Angin Karya Tere Liye Dan Implementasinya. Skripsi. Fakultas Keguruan dan Ilmu Pendidikan. Bahasa dan Seni Universitas Sanata Dharma Yogyakarta.

Moleong, Lexy J. (2013). Metode Penelitian Kualitatif Edisi Revisi. Bandung: PT. Remaja Rosdakarya

Nur, Arafat. (2017). Bulan Kertas. Jakarta: Gramedia.

Nurgiantoro, Burhan. (2010). Penilaian Pembelajaran Bahasa. Yogyakarta: BPFE.

Nurgiantoro, Burhan. (2013). Teori Pengkajian Fiksi. Yogyakarta: Gajah Mada University Press

Tarigan, Guntur. (2011). Prinsip-Prinsip Dasar Sastra. Bandung: Angkasa

Wahida, Karima Nur. (2017). Analisis Pesan Moral dalam Novel Surga Yang Tak Dirindukan Karya Asma Nadia. Skripsi. Fakultas Dakwah dan Komunikasi UIN Alauddin Makasar.

Wicaksono, Andri. (2014). Pengkajian Prosa Fiksi. Bandar lampung: Garudhawaca. 